\title{
Performance Measurement of Banking Supervision: From the Perspective of Banking Supervision Law
}

\author{
Sang-Bing Tsai ${ }^{1}$ \\ ${ }^{1}$ Law School, Nankai University, Tianjin 300071, China \\ E-mail: sangbing@hotmail.com
}

\begin{abstract}
Financial supervision is the power that financial management authorities execute the laws concerned to supervise and monitor financial institutes; the main goal to execute this power is for the whole and safe financial banking business, for financial fair trade and for the maintenance of financial order. Importance-Performance Analysis Model is a method frequently adopted to measure achievement and to analyze competitive strategies. This study is based on IPA method, analyzing the achievement of the bank supervision and then reforms the bank supervision policies according to this analysis. According to the research, it has shown index 1 "capital sufficiency", index 5 "situations of obedience by proper laws", and index 7 "business execution control" are indexes of "Keep up the good work". There are the strength points of Taiwan bank supervision. For the on-going quality achievement, it demands bank's efforts to keep up those good merits.
\end{abstract}

Keywords: Banking Supervision, Financial Supervision Laws, importance-performance analysis model, competitive strategy, performance

\section{Introduction}

There are no differences for financial institutes from other for-profit business enterprises; they exist mainly for business trade, for quality services, and for profits gaining, though financial institutes run their business with deposits from the society. Their influences are farer and wider. Therefore, the government's management of financial institutes should be more severe, to prevent from financial corruption affairs, for maintaining the safety of the banking system [1-3].

With the liberalization and globalization of financial development, innovative financial activities flourishing, and the banking business more and more complicated, the financial system risks also gradually increase with time. To effectively adjust to the rapid change of the financial environment, main countries in the world all devote to carrying out financial reforms[4]. Through reflections on financial supervision system and financial regulations, through the improvement of financial credit risk assessment techniques, the banks are urged to sharpen their risk management and corporation administration, to derive a robust and safe financial system and to enhance the country's financial competitive advantage. Besides, since the unsteady financial banking business will jeopardize the gross economy seriously, the international financial organizations and each country's central bank all aggressively construct and maintain the stable financial framework in recent years, hoping through the systematic analysis and monitoring, to take the proper polices and measures in time for the goal of stabilizing the financial order of its country.

This study is based on the financial supervision laws of Taiwan, discussing on the achievement 
of banks' supervision in Taiwan. Importance-Performance Analysis Model is a method frequently adopted to measure achievement and to analyze competitive strategies. This study is based on IPA method, analyzing the achievement of the bank supervision and then reforms the bank supervision policies according to this analysis.

\section{Literature Review}

\subsection{Financial and Banking Supervision Functions}

Financial supervision is the power that financial management authorities execute the laws concerned to supervise and monitor financial institutes; the main goal to execute this power is for the whole and safe financial banking business, for the rights of depositors, for the need of industrial development, for the financial fair trade, and for the maintenance of financial order.

Functions of the financial supervision include [5-7]:

(1) Stabilizing and Normalizing financial Business

Bank laws are the prerequisite for running financial business. The reason for setting up bank laws is to stabilize and normalize the banking business and to employ the national financial policies with banks' cooperation. Thereof, the foremost reason for the financial supervision is to run the integrated financial business safely.

(2) Ensuring Depositors' Rights

The basic business of the bank is to collect money from the society and create credits to customers. Bank credit needs the trust from all the depositors. For ensuring depositors' rights, the financial supervision management offices set up the deposit insurance system by laws. Through this established system, depositors' trust towards bank payment is certified and furthermore the depositors' rights are ensured.

(3) Adaptation to the Need of Industrial Development

Industries are the heart of economy. Credits are created by banks to go with the development of enterprises from all industries. Banks modularize capital for the need of industries, to assist the development of industries and to make the economy grow up steadily.

\subsection{System and Indexes of Financial Supervision}

In addition to effective modulation of financial supervision policies, within the rapid and diversified change of financial situations, governments of all countries particularly pay much attention to the bank censorship and financial early warning system. On September 1997, Basel Committee on Banking Supervision entitled "Core Principles for Effective Banking Supervision", providing the financial supervision authorities of nations all over the world with the evaluation standard, to assess the quality good or bad of their own financial supervision systems [8].

This paper is built on the ground of pervious literature and studies. We then come up with an evaluation method of the bank supervision achievement. The indexes contained are capital sufficiency, profitable ability, fluidity, board of directors and supervisors' screening, situations of obedience by proper laws, improvement on defections, business execution control, consumers' appeal handling, credit risk management, and business risk management. There are a total of ten indexes listed above. 


\section{Method}

The basic related framework of Importance-Performance Analysis (IPA) was first developed by Martilla and James (1977) and then put into practice [9-12]. IPA proposed the indexes of average scoring of importance and performance in a two dimensional figure. Vertical axis represents importance; horizontal axis represents performance, shown as in figure 1.

Each in four quadrants in IPA method has its own definitions [13-18]:

(1) Keep up the good work: it shows that customers are of high regard for the evaluation index in this section. They are quite satisfactory towards the enterprise achievement; therefore the corresponding issue onto this quadrant is "keep up the good work".

(2) Concentrate here: it reveals that customers keep special focus on the evaluation index in this section but they are not satisfied with the enterprise' performance. As a result, the related issue onto this quadrant is "concentrate here".

(3) Low priority: it demonstrates that customers do not pay special heed to the evaluation index in this section and are unsatisfactory towards the enterprise performance. Hence, the issue concerned onto this quadrant is "low priority".

(4) Possible overkill: it is clear that customers do not give high attention to the evaluation index in this section. However, they feel contented with the enterprise achievement; thus the issue onto this quadrant belongs to "possible overkill".

Through differentiation of those sections, bank managers could make the utmost use of limited resources, to assist the managers with acknowledgment of their own competitive advance or their weakness. This would also equip the managers with the priority order of improvement of banks for lifting up achievement of the bank management. IPA analysis is an easy test to distinguish the good achievement from the bad one. Many scholars have adopted this method on other academic fields enormously. It is a satisfactory tool to clients' need and it's the analytic reference for the improvement priority order [19-24].

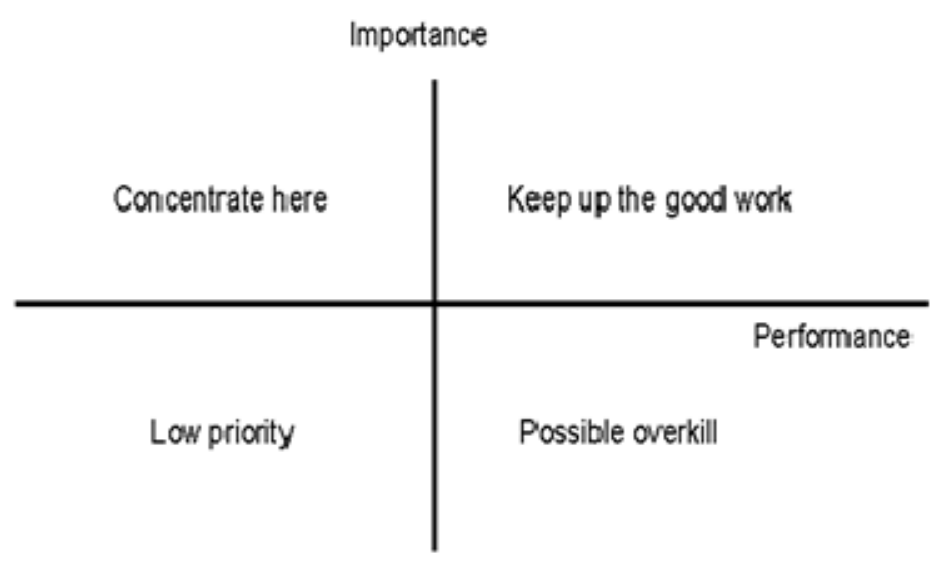

Fig. 1 IPA Chart

\section{Results and Discussion}

Our questionnaire adopts Likert seven points scale, where there are ten measure indexes. The study is comprised of personal opinions gathered from financial experts in Taiwan who express their viewpoints of bank supervision achievement. There are a total of 32 experts, including 8 
Finance department professors from college, 18 bank high-ranked managers, and 6 government financial supervision officers. Formal questionnaires are given out to those financial experts and 30 ones are recollected. The valid questionnaire recovery is $94 \%$.

Our research is based on the average value of "importance" and "performance" from the replied questionnaires as the criteria to judge the performance of each index. Please read the details on following Table 1.

Table 1. Performance Evaluation and Improvement Strategies of Bank Supervision

\begin{tabular}{llccl}
\hline Items & Criteria & Importance & Performance & Improvement Strategies \\
\hline 1 & capital sufficiency & 6.1 & 6.0 & Keep up the good work \\
2 & profitable ability & 5.6 & 5.1 & Low priority \\
3 & fluidity & 5.6 & 5.9 & Possible overkill \\
4 & board of directors and & 6.0 & 5.2 & Concentrate here \\
& supervisors' screening & & & \\
5 & situations of obedience by & 5.9 & 6.2 & Keep up the good work \\
& proper laws & & & \\
6 & improvement on defections & 5.9 & 5.1 & Concentrate here \\
7 & business execution control & 6.1 & 5.9 & Keep up the good work \\
8 & consumers' appeal handling & 5.4 & 5.3 & Low priority \\
9 & credit risk management & 5.7 & 5.7 & Possible overkill \\
10 & business risk management & 5.9 & 5.3 & Concentrate here \\
average & & 5.82 & 5.57 & \\
\hline
\end{tabular}

AS shown in the IPA results, the analysis of achievement evaluation and improvement strategies of Taiwan bank supervision is as follows:

(1) High importance, high performance: the index 1 "capital sufficiency", index 5 "situations of obedience by proper laws", and index 7 "business execution control" are indexes of "Keep up the good work". This is the valuable merit of the bank supervision in Taiwan banking industry. It needs to be maintained and to keep up the good achievement.

(2) High importance, low performance: the index 4 "board of directors and supervisors' screening", index 6 "improvement on defections", and index 10 "business risk management" are indexes of "concentrate here". The banks in Taiwan are required to put more efforts and resources to upgrade the business quality and competitive competency of these 3 indexes. Only then can the banking industry turn the bad quality into good quality of its business. This will also raise the achievement for banks.

(3) Low importance, low performance: index 2 "profitable ability" and index 8 "consumers' appeal handling" are indexes of "low priority". These two indexes could be viewed as the peripheral indexes which are not the first priority indexes. When banks have more resources to invest, those two then might be considered to get improved. 
(4) Low importance, high performance: index 3 "fluidity" and index 9 "credit risk management" are indexes of "possible overkill". Banks in Taiwan have good achievement; however, this could not bring in more achievement to the banking industry. Resources should be transferred to other priority improvement indexes.

\section{Conclusion}

According to our research, it has shown index 1 "capital sufficiency", index 5 "situations of obedience by proper laws", and index 7 "business execution control" are indexes of "Keep up the good work". There are the strength points of Taiwan bank supervision. For the on-going quality achievement, it demands bank's efforts to keep up those good merits. Nevertheless, index 4 "board of directors and supervisors' screening", index 6 "improvement on defections", and index 10 "business risk management" are three indexes of "concentrate here". It is a necessity for banks in Taiwan to invest more resources to lift up the business quality and competitive competence. Only buying upgrading banks themselves can banks strengthen their expertise of service, turning the bad situation back and raising the competitive performance.

\section{References:}

[1] Aebi, V., Sabato, G. \& Schmid, M. 2012. Risk management, corporate governance, and bank performance in the financial crisis. Journal of Banking \& Finance, 36(12), 3213-3226.

[2] Benjamin, C. \& Charles, C. 2014. Bank Panics, Government Guarantees, and the Long-Run Size of the Financial Sector: Evidence from Free-Banking America. Journal of Money Credit and Banking, 46(5), 961-997.

[3] Swami, M. B. 2014. The Impact of liberalization of regulation in Banking Sector: Case Study of Botswana Banking Sector. Open Journal of Finance, 6, 1-10.

[4] Shipra, Bansal \& Yash, P. T. 2014. Comparative Study on Performance Evaluation of Large Cap Equity and Debt Mutual Fund Schemes. Open Journal of Finance, 3, 1-13.

[5] Berger, A. N., Hasan, I. \& Zhou, M. 2009. Bank ownership and efficiency in China: What will happen in the world's largest nation? Journal of Banking \& Finance, 33(1), 113-130.

[6] Nuno Ferreira \& Manuela, M. O. 2014. An Analysis of Equity Markets Cointegration in the European Sovereign Debt Crisis. . Open Journal of Finance, 6, 11-19.

[7] Mora, N. 2014. Reason for Reserve? Reserve Requirements and Credit. Journal of Money Credit and Banking, 46(2), 469-501.

[8] Jiang, G. J. \& Lo, I. 2014. Private information flow and price discovery in the U.S. treasury market. Journal of Banking \& Finance, 47(10), 118-133.

[9] Tsai, S.B., Huang, C.Y., Wang, C.K., Chen, Q., et al. 2016. Using a Mixed Model to Evaluate Job Satisfaction in High-Tech Industries. Plos One, 11(5): e0154071. doi:10.1371/journal.pone.0154071

[10] Tsai, S.B. 2016. Using Grey Models for Forecasting China's Growth Trends in Renewable Energy Consumption. Clean Technologies and Environmental Policy, 18, 563-571.

[11] Zhou, J. Wang, Q., Tsai, S.B., et al. 2016. How to Evaluate the Job Satisfaction of Development Personnel. IEEE Transactions On Systems Man Cybernetics-Systems. 


\subsection{9/TSMC.2016.2519860.}

[12] Su, J.M., Lee, S.C., Tsai, S.B., et al. 2016. A Comprehensive Survey of the Relationship between Self-efficacy and Performance for the Governmental Auditors. SpringerPlus, 5:508. DOI: 10.1186/s40064-016-2104-X.

[13] Qu, Q., Chen, K.Y., Wei, Y.M., et al. 2015. Using Hybrid Model to Evaluate Performance of Innovation and Technology Professionals in Marine Logistics Industry Mathematical Problems in Engineering, Article ID 361275, 8 pages, http://dx.doi.org/10.1155/2015/361275.

[14] Tsai, S.B., Xue, Y., Zhang, J., et al. 2016. Models for Forecasting Growth Trends in Renewable Energy. Renewable \& Sustainable Energy Reviews. DOI: 10.1016/j.rser.2016.06.001.

[15] Lee, Y.C., Chu, W.H., Chen, Q., et al. 2016. Integrating DEMATEL Model and Failure Mode and Effects Analysis to Determine the Priority in Solving Production Problems. Advances in Mechanical Engineering, 8(4), 1-12.

[16] Huang, P.Y., Wu, T.S., Chen, L.J., Tsai, S.B., et al. 2015. An Empirical Research on Management Innovation of High Technology Manufacturers. Advances in Mechanical Engineering, 7(7), 1-14. DOI: 10.1177/1687814015593679.

[17] Chang, S.F., Chang, J.C., Lin, K.H., Tsai, S.B., et al. 2014. Measuring the Service Quality of E - Commerce. International Journal of Web Services Research, 11(3), 96-115.

[18] Lee, Y.C., Wang, Y.C., Chien, C.H., Wu, C.H., et al. 2016. Applying Revised Gap Analysis Model in Measuring Hotel Service Quality, SpringerPlus, 5:1191. DOI 10.1186/s40064-016-2823-z.

[19] Lee, Y.C., Wang, Y.C., Lu, S.C. Hsieh, Y.F., et al. 2016. An Empirical Research on Customer Satisfaction Study: A Consideration of Different Levels of Performance. SpringerPlus, 5:1577. DOI 10.1186/s40064-016-3208-z.

[20] Deng, Y. \& Chan, F.T.S. 2011. A new fuzzy dempster MCDM method and its application in supplier selection. Expert Systems with Applications, 38(8), 9854-9861.

[21] Deng,X.Y., Hu, Y., Deng Y., \& Mahadevan,S. 2014. Environmental impact assessment impact assessment based on numbers. Expert Systems with Applications, 41(2), 635-643.

[22] Hsiao-Ming Chen, Chia-Huei Wu, Sang-Bing Tsai, Jian Yu, et al. 2016. Exploring key factors in online shopping with a hybrid model. SpringerPlus, 5:2046. DOI 10.1186/s40064-016-3746-4.

[23] Sang-Bing Tsai, Kuan-Yu Chen, Hongrui Zhao, Yu-Min Wei, et al. 2016. Using a Mixed Model to Explore Evaluation Criteria for Bank Supervision: A Banking Supervision Law Perspective. PLoS ONE, 11(12): e0167710. doi:10.1371/journal.pone.0167710.

[24] Sang-Bing Tsai, Guodong Li, Chia-Huei Wu, Yuxiang Zheng \& Jiangtao Wang. 2016. An empirical research on evaluating banks' credit assessment of corporate customers. SpringerPlus, 5:2088. DOI 10.1186/s40064-016-3774-0. 